\title{
TNF-alpha impairs regulation of muscle oxidative phenotype: implications for cachexia?
}

Citation for published version (APA):

Remels, A. H. V., Gosker, H. R., Schrauwen, P., Hommelberg, P. P., Sliwinski, P., Polkey, M., Galdiz, J., Wouters, E. F. M., Langen, R. C. J., \& Schols, A. M. W. J. (2010). TNF-alpha impairs regulation of muscle oxidative phenotype: implications for cachexia? Faseb Journal, 24(12), 5052-5062.

https://doi.org/10.1096/fj.09-150714

Document status and date:

Published: 01/12/2010

DOI:

10.1096/fj.09-150714

Document Version:

Publisher's PDF, also known as Version of record

Document license:

Taverne

Please check the document version of this publication:

- A submitted manuscript is the version of the article upon submission and before peer-review. There can be important differences between the submitted version and the official published version of record.

People interested in the research are advised to contact the author for the final version of the publication, or visit the DOI to the publisher's website.

- The final author version and the galley proof are versions of the publication after peer review.

- The final published version features the final layout of the paper including the volume, issue and page numbers.

Link to publication

\footnotetext{
General rights rights.

- You may freely distribute the URL identifying the publication in the public portal. please follow below link for the End User Agreement:

www.umlib.nl/taverne-license

Take down policy

If you believe that this document breaches copyright please contact us at:

repository@maastrichtuniversity.nl

providing details and we will investigate your claim.
}

Copyright and moral rights for the publications made accessible in the public portal are retained by the authors and/or other copyright owners and it is a condition of accessing publications that users recognise and abide by the legal requirements associated with these

- Users may download and print one copy of any publication from the public portal for the purpose of private study or research.

- You may not further distribute the material or use it for any profit-making activity or commercial gain

If the publication is distributed under the terms of Article $25 \mathrm{fa}$ of the Dutch Copyright Act, indicated by the "Taverne" license above, 


\title{
TNF- $\alpha$ impairs regulation of muscle oxidative phenotype: implications for cachexia?
}

\author{
A. H. V. Remels, ${ }^{*}$ H. R. Gosker, ${ }^{*}$ P. Schrauwen, ${ }^{\dagger}$ P. P. H. Hommelberg, ${ }^{\dagger}$ \\ P. Sliwinski, ${ }^{\ddagger}$ M. Polkey, ${ }^{\S}$ J. Galdiz,,$\|$ E. F. M. Wouters, ${ }^{*}$, Il R. C. J. Langen, ${ }^{*}$ \\ and A. M. W. J. Schols*, \\ Department of *Respiratory Medicine and ${ }^{\dagger}$ Department of Human Biology, NUTRIM School for \\ Nutrition, Toxicology, and Metabolism, Maastricht University Medical Centre, Maastricht, The \\ Netherlands; ${ }^{\ddagger}$ Department of Respiratory Medicine, Institute of Tuberculosis and Lung Diseases, \\ Warsaw, Poland; 'Respiratory Medicine Department, Royal Brompton Hospital, Imperial College, \\ London, UK; "Pneumology Department and Research Unit, Cruces Hospital, Basque Country \\ University, Barakaldo, Spain; and ${ }^{\pi}$ Center for Integrated Rehabilitation of Organ Failure (CIRO), \\ Horn, The Netherlands
}

ABSTRACT Chronic obstructive pulmonary disease (COPD) is characterized by weight loss, muscle wasting (in advanced disease ultimately resulting in cachexia), and loss of muscle oxidative phenotype (oxphen). This study investigates the effect of inflammation (as a determinant of muscle wasting) on muscle oxphen by using cell studies combined with analyses of muscle biopsies of patients with COPD and control participants. We analyzed markers (citrate synthase, $\beta$-hydroxyacyl-CoA dehydrogenase, and cytochrome c oxidase IV) and regulators (PGC-1 $\alpha, P P A R-\alpha$, and Tfam) of oxphen in vastus lateralis muscle biopsies of patients with advanced COPD and healthy smoking control participants. Here 17 of 73 patients exhibited elevated muscle TNF- $\alpha$ mRNA levels. In these patients, significantly lower mRNA levels of all oxidative markers/regulators were found. Interestingly, these patients also had a significantly lower body mass index and tended to have less muscle mass. In cultured muscle cells, mitochondrial protein content and myosin heavy chain isoform I (but not II) protein and mRNA levels were reduced on chronic TNF- $\alpha$ stimulation. TNF- $\alpha$ also reduced mitochondrial respiration in a nuclear factor kappaB (NF$\kappa B)$-dependent manner. Importantly, TNF- $\alpha$-induced NF-кB activation decreased promoter transactivation and transcriptional activity of regulators of mitochondrial biogenesis and muscle oxphen. In conclusion, these results demonstrate that TNF- $\alpha$ impairs muscle oxphen in a NF-кB-dependent manner.-Remels, A. H. V., Gosker, H. R., Schrauwen, P., Hommelberg, P. P. H., Sliwinski, P., Polkey, M., Galdiz, J., Wouters, E. F. M., Langen, R. C. J., Schols, A. M. W. J. TNF- $\alpha$ impairs regulation of muscle oxidative phenotype: implications for cachexia? FASEB J. 24, 5052-5062 (2010). www.fasebj.org

Key Words: inflammation $\cdot$ nuclear factor $\kappa$ $B \cdot$ peroxisome proliferator-activated receptors $\cdot$ mitochondrial transcription factor $A$
CAchexia is a COMPLEX AnD disabling syndrome that occurs in the course of many chronic diseases and cancer $(1,2)$. Nevertheless, it receives limited attention in clinical practice because the accelerated muscle wasting, which distinguishes this condition from malnutrition, is considered irreversible with current anabolic intervention strategies. More insight into the etiology of this syndrome is thus urgently needed. The prevalence of cachexia is remarkably high in chronic obstructive pulmonary disease (COPD) (3-5).

COPD is a disabling chronic lung disease characterized not only by progressive, irreversible airflow obstruction but also by skeletal muscle dysfunction and an abnormal inflammatory response in lung and circulation, including elevated levels of the proinflammatory cytokine tumor necrosis factor alpha $(\mathrm{TNF}-\alpha)(6,7)$. Skeletal muscle dysfunction in advanced COPD is characterized not only by wasting of predominantly type II muscle fibers but also by a decreased oxidative phenotype (oxphen) as evidenced by a type I $\rightarrow$ II fiber type shift and a decreased oxidative enzyme capacity and mitochondrial content $(8$, 9). COPD is therefore an interesting clinical cachexia model for translational research.

Beutler and Cerami were the first to describe a link between TNF- $\alpha$, initially named cachectin, and a cachectic phenotype characterized by anorexia, anemia, and weakness (10). To date, a causal relationship between TNF- $\alpha$-induced inflammatory signaling and muscle wasting has been firmly established in experimental models (11), and associations with acute and advanced disease have been found (2). However, although Tracey et al. (12) and Lee et al. (13) 20 yr ago described effects of TNF- $\alpha$ on skeletal

\footnotetext{
${ }^{1}$ Correspondence: Department of Respiratory Medicine, Maastricht University Medical Centre, P.O. Box 5800, 6202 AZ Maastricht, The Netherlands. E-mail: a.schols@pul.unimaas.nl doi: 10.1096/fj.09-150714

This article includes supplemental data. Please visit http:// $w w w$.fasebj.org to obtain this information.
} 
muscle plasma membrane potential and glucose metabolism, respectively, effects and underlying mechanisms of local inflammatory signaling on muscle oxphen surprisingly have not yet been addressed thus far.

Previously we demonstrated that expression levels of master regulators of muscle oxphen, including peroxisome proliferator-activated receptors (PPARs), PPAR- $\gamma$ coactivator $1 \alpha(P G C-1 \alpha)$, and mitochondrial transcription factor A (Tfam), were reduced in quadriceps muscle of patients with COPD, being most pronounced in the cachectic subgroup. Intriguingly, expression levels of these markers correlated inversely with TNF- $\alpha$ levels in plasma (14). We hypothesized that impaired regulation of oxphen could result directly from TNF- $\alpha$-induced activation of nuclear factor $\kappa \mathrm{B}(\mathrm{NF}-\kappa \mathrm{B})$, a master signaling pathway relaying inflammatory signals, in skeletal muscle. Our hypothesis was tested using a translational approach by combining in vitro studies in C2C12 muscle cells with muscle biopsy analysis in appropriately phenotyped patients with COPD.

\section{MATERIALS AND METHODS}

\section{Subjects}

Data were extracted from the ENIGMA (European Network for Investigating the Global Mechanisms of Muscle Abnormalities in COPD; www.pul.unimaas.nl/enigma) database containing skeletal muscle samples of the vastus lateralis from patients with advanced COPD and healthy age-matched smoking control participants. A diagnosis of COPD was established on the basis of the guidelines of the Global Initiative for Chronic Obstructive Lung Disease (15). We deliberately compared patients to healthy smoking control subjects because smoking is the most important risk factor of COPD, and we previously showed in a mouse model that smoking per se may affect muscle oxphen (16). In addition, we previously also showed a relationship between low body mass index (BMI), fat-free mass index (FFMI), and smoking behavior (17). Additional details are provided in the Supplemental Material.

\section{Cell culture}

The murine skeletal muscle cell line C2C12 was obtained from the American Type Culture Collection (ATCC; CRL1772; Manassas, VA, USA). Myoblasts were cultured as described previously (18). In short, C2C12 myoblasts were cultured in growth medium (GM) composed of low-glucose Dulbecco's mdified Eagle's medium (DMEM) containing antibiotics $(50 \mathrm{U} / \mathrm{ml}$ penicillin and $50 \mu \mathrm{g} / \mathrm{ml}$ streptomycin) and $9 \%$ (v/v) fetal bovine serum (FBS) (all from Life Technologies, Rockville, MD, USA). To induce differentiation, cells were washed in Hank's balanced salt solution (HBSS), and GM was replaced with differentiation medium (DM), which consisted of DMEM with $0.5 \%$ heatinactivated $\left(30 \mathrm{~min}\right.$ at $\left.56^{\circ} \mathrm{C}\right) \mathrm{FBS}$ and antibiotics. The L6 rat skeletal muscle cell line was obtained from the ATCC (CRL1458) and was cultured in GM, composed of $\alpha$-MEM (Life Technologies; Invitrogen, Rockville, MD, USA) containing 9\% (v/v) FBS and antibiotics. After $24 \mathrm{~h}$ of culturing in GM, differentiation was induced by replacing GM with DM containing $\alpha$-MEM with 2\% (v/v) heat-inactivated FBS and antibiotics.

\section{Transfections and plasmids}

C2C12 cells were stably or transiently transfected with the human CPT-1 B promoter (HCBP; PPAR reporter) luciferase plasmid (pSG5; Stratagene, La Jolla, CA, USA) (PPAR reporter cell line). As a control, cells were stably or transiently transfected with equal amounts of empty vector PcDNA3.1 (Invitrogen). For assessment of Tfam or NRF-1 promoter activity, cells were transiently transfected with a mtTFARC4wt/pGL3 or p4xNRF-1Luc luciferase construct $(19,20)$. Cells were transfected by nanofectin (PAA, Pasching, Austria) according to the manufacturer's instructions. Additional details are provided in the Supplemental Material.

\section{Reporter assays}

Cells were harvested by washing $2 \times$ with cold PBS and subsequent lysis by adding $(100 \mu \mathrm{l}) 1 \times$ Reporter Lysis Buffer (Promega, Madison, WI, USA) and incubation on ice for 10 min. Cell lysates were centrifuged (14,000 rpm, $1 \mathrm{~min})$, and supernatants were snap-frozen and stored at $-80^{\circ} \mathrm{C}$ for later analysis. Luciferase activity was measured according to the manufacturer's instructions (Promega) and corrected for total protein content (Bio-Rad, Hercules, CA, USA). Additional details are provided in the Supplemental Material.

\section{QPCR and enzyme-linked immunosorbent assay (ELISA) for TNF- $\alpha$ determination}

The presence of TNF- $\alpha$ protein in cell culture medium was determined with an ELISA kit directed against mouse TNF- $\alpha$ (R\&D Systems, Minneapolis, MN, USA). In short, C2C12 myotubes (d 5 of differentiation) were stimulated with TNF- $\alpha$ (10 $\mathrm{ng} / \mathrm{ml})$ for $2 \mathrm{~h}$ or with IL-1 $\beta(10 \mathrm{ng} / \mathrm{ml})$ for $24 \mathrm{~h}$. In the case of TNF- $\alpha$ stimulation, recombinant TNF- $\alpha$ was washed out after the $2 \mathrm{~h}$ stimulation period by 5 serial washes with $1 \mathrm{ml}$ of HBSS, and new DM was added to the cell culture. Medium was collected $24 \mathrm{~h}$ later for determination of TNF- $\alpha$ protein. For determination of TNF- $\alpha$ mRNA, myotubes were stimulated with IL-1 $\beta$ (10 $\mathrm{ng} / \mathrm{ml}$ ) for $2 \mathrm{~h}$, and TNF- $\alpha$ mRNA was determined. Additional details regarding QPCR methods and primer characteristics (Table S1) are provided in the Supplemental Material.

\section{Enzyme activity assay}

Activity levels of creatine kinase (CK) were measured as described previously (21). Enzyme activity levels were corrected for total protein content. Total protein content was determined using a detergent compatible protein determination assay (Bio-Rad).

\section{Mitochondrial respiration}

Respiration was measured using a respirometer (Oxygraph 2K; Oroboros Instruments). Oxygen consumption $(\mathrm{nM} / \mathrm{s})$ was calculated as a negative time derivative of oxygen concentration $(\mu \mathrm{M})$. Additional details are provided in the Supplemental Material.

\section{Western blot analysis}

Whole-cell lysates were prepared as described previously (22). Western blots were corrected for total protein and an internal loading control. Additional details are provided in the Supplemental Material. 


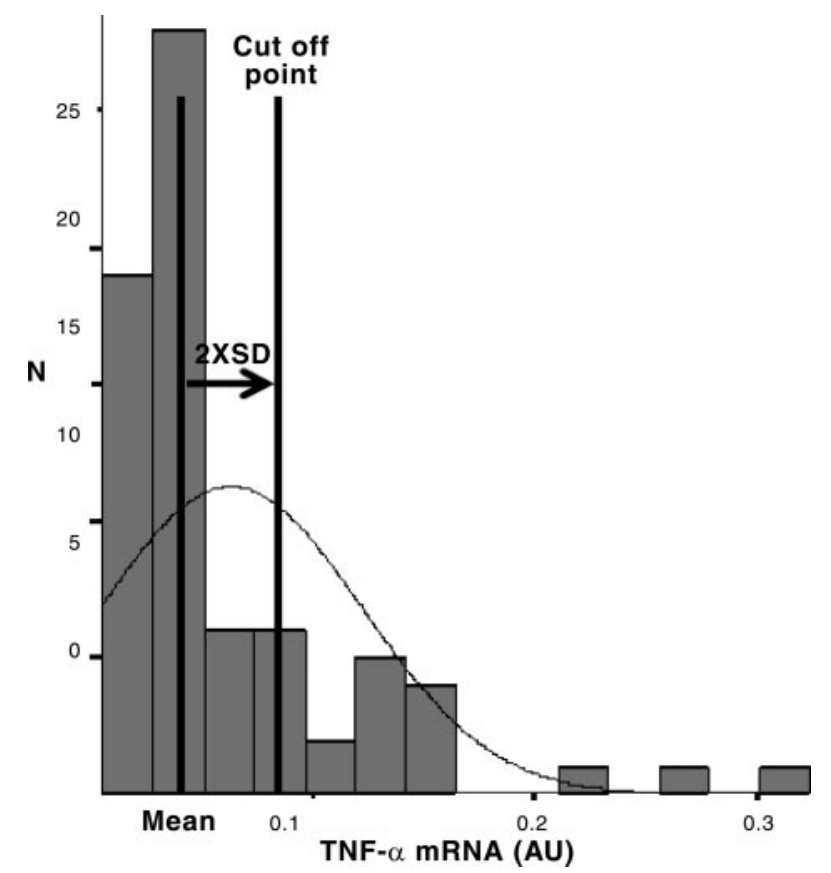

Figure 1. Assessment of TNF- $\alpha$ mRNA expression levels in muscle of patients with COPD. Transcript levels of $T N F-\alpha$ were assessed in muscle biopsies of control subjects $(n=10)$ and patients with COPD $(n=73)$. Gene expression levels were normalized by calculating a normalization value based on 5 housekeeping genes (cyclophilin A, $\beta 2$-microglobuline, glyceraldehyde-3-phosphate dehydrogenase, hypoxanthine-guanine phosphoribosyltransferase, and $\beta$-actin) using GeNorm software. Patients having muscle $T N F-\alpha$ mRNA levels $>$ mean +2 sD of control subjects were categorized in the high-TNF- $\alpha$ patient group $(n=17)$.

\section{Electrophoretic mobility shift assay (EMSA)}

NF-кB DNA binding activity was assessed in nuclear extracts by analysis of complexes binding to an oligonucleotide con- taining a $\kappa \mathrm{B}$ consensus sequence (Santa Cruz Biotechnology, Santa Cruz, CA, USA). Nuclear extracts were prepared as described previously (18). Additional details are provided in the Supplemental Material.

\section{Statistics}

Data were analyzed according to the guidelines of Altman et al. (23) using SPSS (SPSS Inc., Chicago, IL, USA). Nonparametric tests, analysis of variance (ANOVA), or correlation analysis (Pearson) was used when appropriate. Data are represented as the mean $\pm \mathrm{SD}$. A 2-tailed probability value of less than 0.05 was considered to be significant.

\section{RESULTS}

\section{Reduced muscle oxidative gene expression in patients with COPD and muscle inflammation}

Patients were divided into subgroups based on $T N F-\alpha$ mRNA expression levels in muscle (Fig. 1). TNF- $\alpha$ protein was not detectable in the muscle biopsies. Patient characteristics after post hoc analysis by muscle $T N F-\alpha$ transcript levels are summarized in Table 1. Between patient subgroups, no differences were observed in standard lung function tests or anthropometric parameters (Table 1). Patients with high muscle $T N F-\alpha$ levels, however, revealed a significantly lower BMI $(P \leq 0.05)$ and a tendency toward a lower FFMI compared to control subjects $(P=0.10)$ (Fig. 2). Moreover, in these patients muscle mRNA expression levels of genes involved in mitochondrial oxidative metabolism such as citrate synthase (CS), $\beta$-hydroxyacyl-CoA dehydrogenase (HAD), and cytochrome $c$ oxidase subunit 4 (COXIV) were lower $(P \leq 0.001)$, although expression of the glycolytic gene hexokinase 2 (HKII) was higher $(P=0.005)$ com-

TABLE 1. Patient characteristics and skeletal muscle gene expression

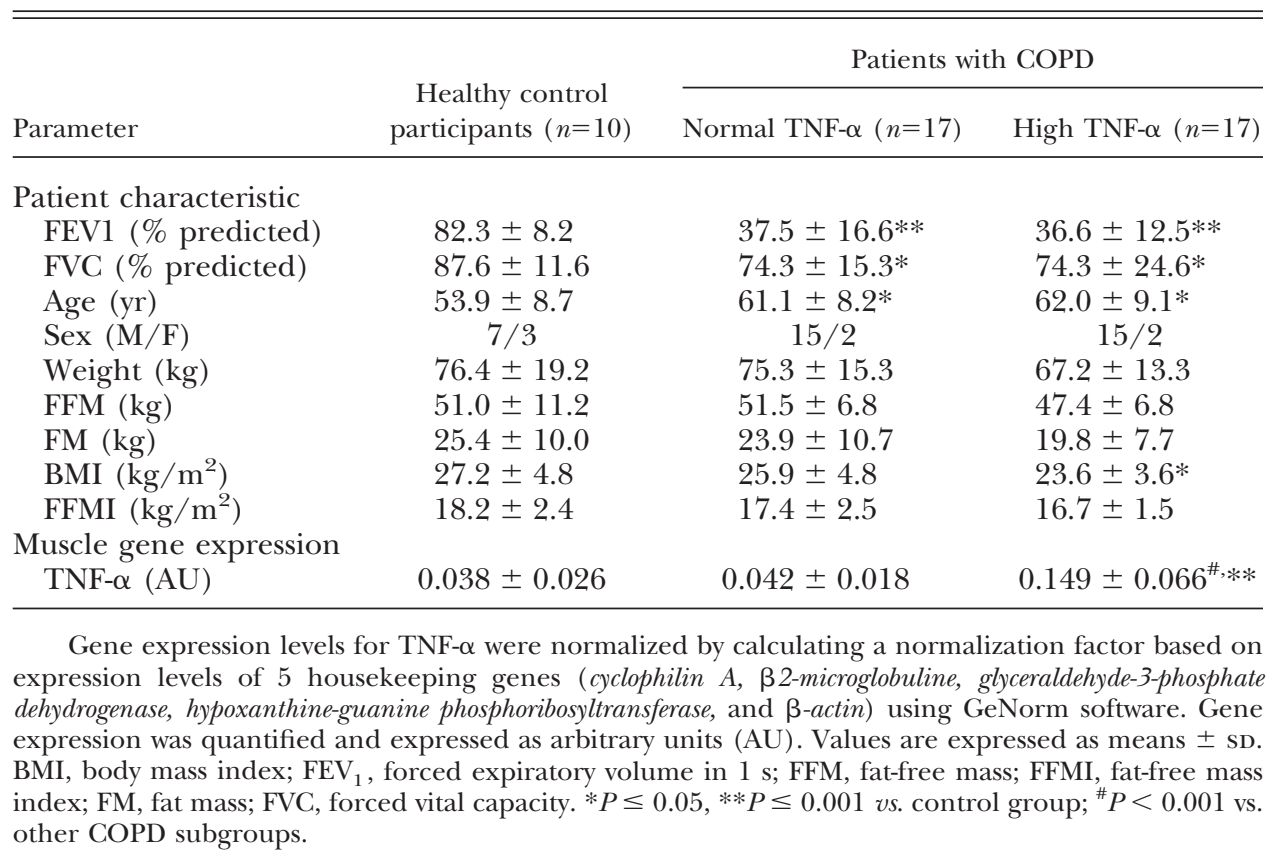




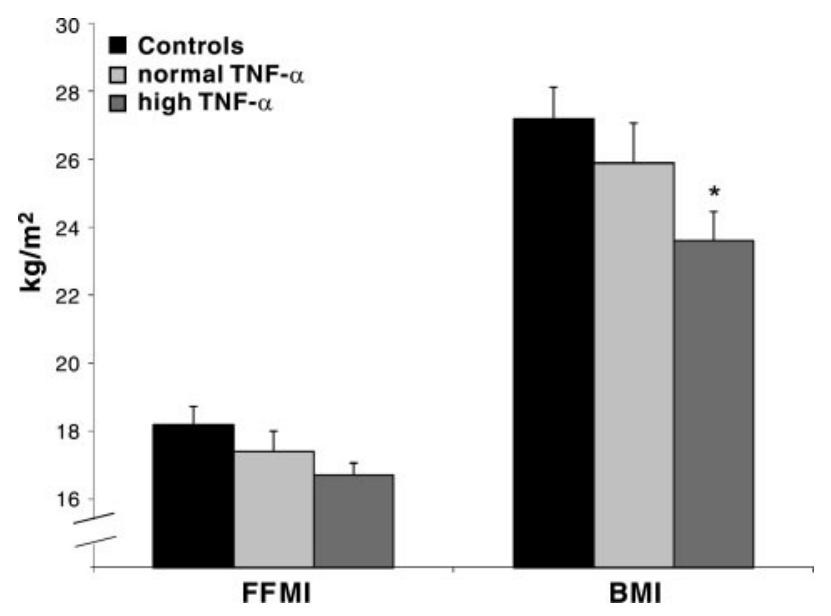

Figure 2. FFMI and BMI are reduced in patients with COPD with high muscle $T N F-\alpha$ mRNA expression. FFMI and BMI were assessed in control subjects $(n=10)$ and patients with COPD characterized by high $(n=17)$ or normal $(n=17)$ muscle $T N F-\alpha$ mRNA expression. All data are expressed as means $\pm \mathrm{SE} . * P \leq 0.05$ vs. control.

pared to patients and control participants with normal muscle $T N F-\alpha$ mRNA levels (Fig. 3A). Accordingly, muscle $T N F-\alpha$ transcript levels correlated negatively with transcript levels of $C S$ and $H A D$ and positively with transcript levels of $H K I I(r=-0.614$, $r=-0.514$, and $r=0.624$, respectively; $P \leq 0.001$ ). Furthermore, these patients were characterized by lower muscle expression levels of several key regulators of skeletal muscle oxphen (PPAR- $\alpha, P G C-1 \alpha$, and Tfam) compared with patients and control participants with normal $T N F-\alpha$ expression levels in muscle $(P=0.001$, $P=0.003$, and $P=0.004$, respectively) (Fig. $3 B$ ).

\section{Inflammatory cytokines induce TNF- $\alpha$ mRNA expression and TNF- $\alpha$ protein secretion in C2C12 myotubes}

TNF $-\alpha$ mRNA induction by TNF- $\alpha$ stimulation of C2C12 myotubes has been described by our group previously (24). Furthermore, induction of $T N F-\alpha$ mRNA was also shown in muscle of mice subject to intramuscular injections with TNF- $\alpha$ (24). In line with this, in the present study, IL-1 $\beta$ stimulation (as an alternative inflammatory stimulus) of C2C12 myotubes also resulted in an induction of $T N F-\alpha$ mRNA compared to vehicle-treated cells (1.303 \pm 0.159 vs. $0.714 \pm 0.131 \mathrm{AU} ; P \leq 0.05$; corrected for the housekeeper cyclophilin A). Furthermore, TNF- $\alpha$ as well as IL-1 $\beta$ stimulation of mature C2C12 myotubes resulted in secretion of significant amounts of TNF- $\alpha$ protein $(33.03 \pm 3.05 \mathrm{pg} / \mathrm{ml}$ and $20.84 \pm 9.58 \mathrm{pg} / \mathrm{ml}$, respectively; $P \leq 0.01)$ in the culture medium, while TNF- $\alpha$ protein was not detectable in supernatant of nonstimulated cultures. Based on the induction of TNF- $\alpha$ mRNA and $\mathrm{TNF}-\alpha$ protein on inflammatory stimuli (autocrine/ paracrine effects), we further investigated the direct effects of TNF- $\alpha$ on muscle oxphen in C2C12 myotubes.

\section{TNF- $\alpha$ impairs skeletal muscle oxphen in vitro}

Myotubes chronically treated with TNF- $\alpha$ displayed significantly lower basal and maximal mitochondrial $\mathrm{O}_{2}$ consumption rates compared to vehicle-treated cells (Fig. 4A). In concordance, chronic TNF- $\alpha$ exposure resulted in significantly decreased protein levels of subunits of mitochondrial oxphos complexes II, III, and V (complex IV was not detectable). Protein content of oxphos complex I was also decreased after TNF- $\alpha$, but this just failed to reach statistical significance (Fig. $4 B, C$ ). After TNF- $\alpha$ treatment a selective reduction of MyHC slow (type I) protein and mRNA abundance was observed compared to vehicle-treated cells. MyHC fast (type II) protein levels and mRNA levels were unaltered or slightly elevated, respectively (Fig. 5). TNF- $\alpha$ stimulation starting at $d 3$ or 5 of differentiation yielded similar results for respiration measurements and MyHC protein abundance (Supplemental Fig. S1).

Because development of muscle oxphen parallels the process of myogenic differentiation and TNF- $\alpha$ is known to inhibit early differentiation, the response of several differentiation markers on chronic TNF- $\alpha$ stimulation was investigated. An important result was that myogenic index, which reflects the proportion of nuclei incorporated into myotubes and serves as a marker of morphological differentiation, was not significantly altered (50.4 \pm 2.8 vs. $51.2 \pm 3.4 \%$ ), and crea-
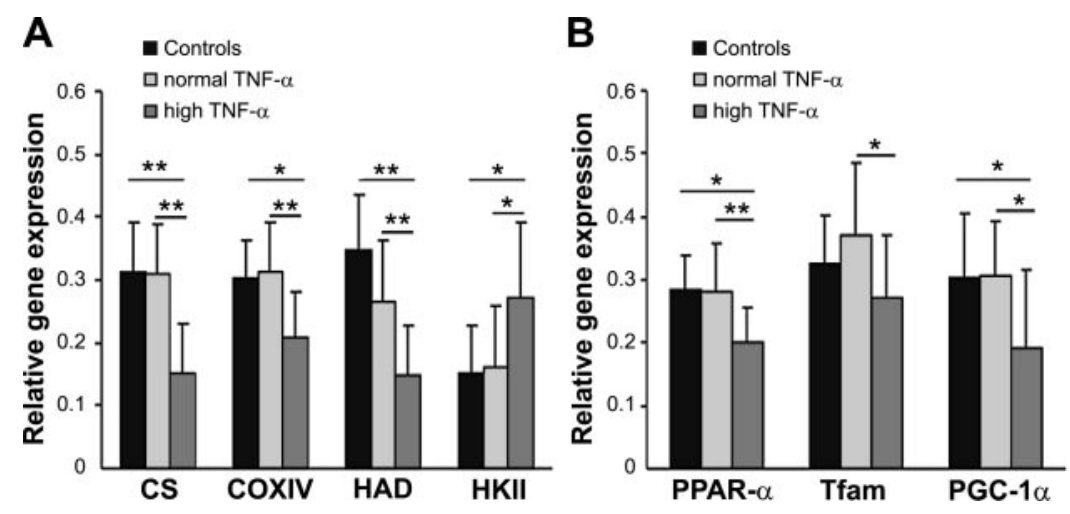

Figure 3. Oxidative gene expression is reduced in skeletal muscle of patients with COPD with high muscle $T N F-\alpha$ mRNA expression. Transcript levels of oxidative genes and their regulators were assessed in control subjects $(n=10)$ and patients with COPD characterized by high $(n=17)$ or normal $(n=17)$ muscle $T N F-\alpha$ mRNA expression. Gene expression levels were normalized by calculating a normalization value based on 5 housekeeping genes (cyclophilin A, $\beta 2$-microglobuline, glyceraldehyde-3-phosphate dehydrogenase, hypoxanthine-guanine phosphoribosyltransferase, and $\beta$-actin) using GeNorm software. $* P \leq 0.05$; $* * P \leq 0.001$. All data are expressed as means \pm SD. 
A

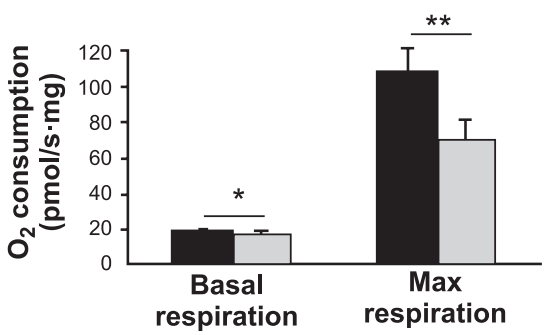

B

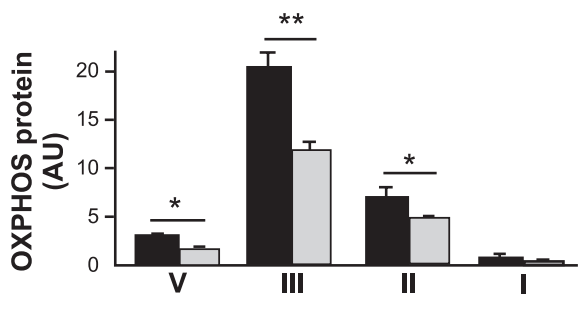

C

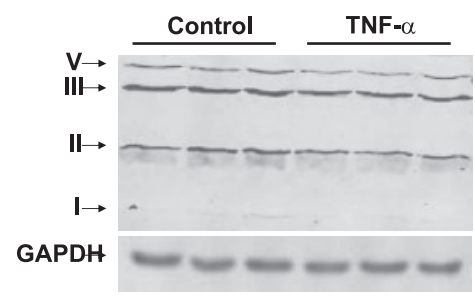

Figure 4. TNF- $\alpha$ impairs oxphen in C2C12 cells. C2C12 myoblasts were differentiated for 3 d in DM. Myotubes were stimulated with vehicle (BSA; control) or TNF- $\alpha(10 \mathrm{ng} / \mathrm{ml})$ for an additional $120 \mathrm{~h}$. Cells were harvested, and mitochondrial respiration rates as well as oxphos protein content were determined. All parameters were corrected for total protein content. A) The following substances were added to the respiration chambers in the following order and final concentration: digitonin ( $1 \mu \mathrm{l}$; 0.5 $\mu \mathrm{g} / \mathrm{ml})$, malate $(5 \mu \mathrm{l} ; 2 \mathrm{mM})$, palmitoyl-carnitine $(10 \mu \mathrm{l} ; 50 \mu \mathrm{M})$, and ADP $(20 \mu \mathrm{l} ; 5 \mathrm{mM})$ followed by FCCP (1 $\mu \mathrm{l} ; 0.5 \mu \mathrm{M}$ titration), and oxygen consumption was measured. $B$ ) Proteins involved in the mitochondrial respiration chain were quantified by Western blot analysis. C) Representative picture of the original blot. Protein levels are given as arbitrary units (AU). All data are expressed as means \pm sD from triplicate samples $(n=3$ experiments). $* P \leq 0.05 ; * * P \leq 0.001$.

tine kinase activity, as a marker of biochemical differentiation, remained unchanged on chronic $\mathrm{TNF}-\alpha$ treatment $(0.47 \pm 0.08$ vs. $0.43 \pm 0.09$; starting $\mathrm{TNF}-\alpha$ stimulation after 3 or $5 \mathrm{~d}$ of differentiation, respectively). In addition, myotube viability was unaffected on chronic TNF- $\alpha$ stimulation, as revealed by routine microscopic inspection (Supplemental Fig. S2).

\section{TNF- $\alpha$ reduces expression levels of regulators of muscle oxphen}

Chronic TNF- $\alpha$ treatment resulted in significantly decreased mRNA levels of PPAR- $\alpha, P G C-1 \alpha$, and Tfam (Fig. 6).
TNF- $\alpha$ reduces transcriptional activity and promoter transactivation of major regulators of skeletal muscle oxphen

Chronic TNF- $\alpha$ stimulation of myotubes resulted in reduced $(-50 \%)$ basal- (Fig. 7A) and ligand-induced (Supplemental Fig. S3A) PPAR transcriptional activity in myotubes. In addition, PPAR transcriptional activity in myoblasts induced by overexpression of PPAR- $\alpha, \delta, \gamma$, or PGC- $1 \alpha$ was inhibited by TNF- $\alpha$ to the same extent (Supplemental Fig. S3B). TNF- $\alpha$ also reduced nuclear respiratory factor 1 (NRF-1) as well as Tfam promoter activity levels in myoblasts by $\sim 50 \%$ (Fig. $7 B$ ).
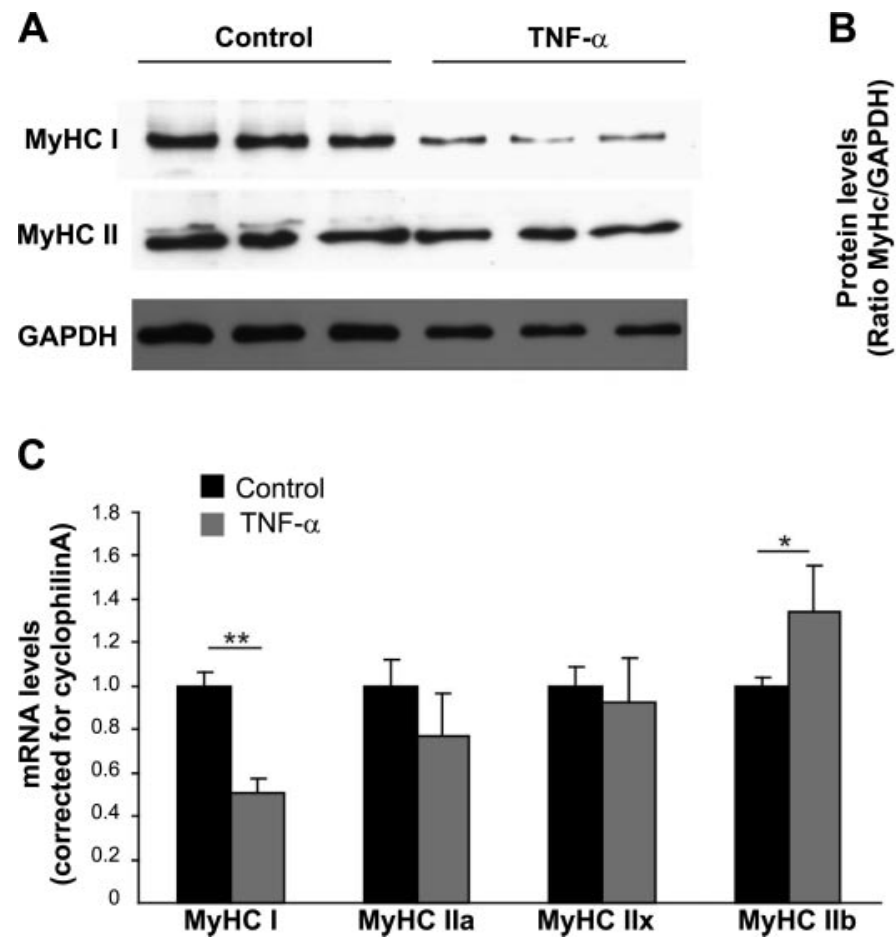

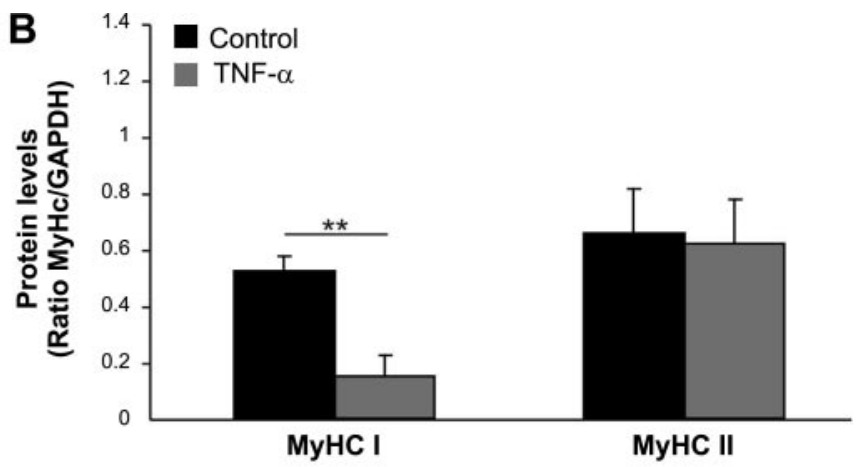

Figure 5. TNF- $\alpha$ alters MyHC profile in C2C12 cells. C2C12 myoblasts were differentiated for $3 \mathrm{~d}$ in DM. Myotubes were stimulated with vehicle (BSA; control) or $\mathrm{TNF}-\alpha(10 \mathrm{ng} / \mathrm{ml})$ for an additional $120 \mathrm{~h}$. Cells were harvested, and MyHC profile was determined at the protein and mRNA level. $A, B$ ) MyHC protein expression was assessed and corrected for total protein content. GAPDH protein levels were used as a loading control. C) Gene expression levels were normalized for cyclophilin $A$ as a representative housekeeping gene. Values are expressed as means $\pm \mathrm{SD}$. ${ }^{*} P \leq 0.05, * * P \leq$ 0.001 vs. control. All data are expressed as means \pm SD from triplicate samples ( $n=3$ experiments). 


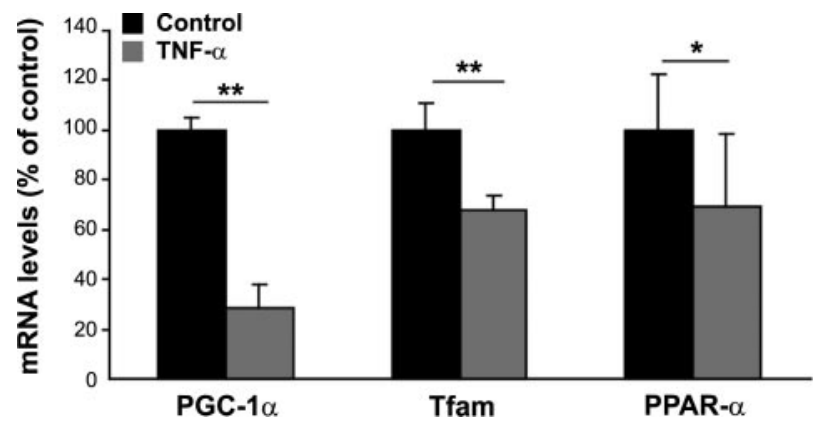

Figure 6. TNF- $\alpha$ reduces expression of regulators of skeletal muscle oxphen. C2C12 myoblasts were differentiated for $3 \mathrm{~d}$ in DM. Myotubes were stimulated with vehicle (BSA; control) or TNF- $\alpha(10 \mathrm{ng} / \mathrm{ml})$ for an additional $120 \mathrm{~h}$. Gene expression levels were normalized for cyclophilin $A$ as a representative housekeeping gene. Gene expression was quantified and expressed as percentage of control from triplicate samples $(n=3$ experiments). Values are expressed as means \pm SD. $* P \leq 0.05, * * P \leq 0.01$ vs. controls.

NF- $\kappa \mathrm{B}$ signaling is required for impairment of transcriptional regulation of muscle oxphen by TNF- $\alpha$

Effectiveness of inflammatory cytokines and constructs encoding NF-KB subunits was confirmed using a stable NF-кB reporter cell line (Supplemental Fig. S4). As illustrated in Fig. 8A, expression of the super-repressor mutant form of the inhibitory $\kappa \mathrm{B} \alpha$ protein $(\mathrm{I} \kappa \mathrm{B} \alpha-\mathrm{SR})$ fully abolished the effect of TNF- $\alpha$ on PPAR transcriptional activity, showing the requirement of intact NF- $\mathrm{B}$ signaling for the effects of TNF- $\alpha$. Conversely, activation of NF- $\kappa$ B using constitutive active IкB kinase $\beta$ (с.а. IKK- $\beta$ ) was sufficient to inhibit PPAR transcriptional activity, which again was restored when the IкB $\alpha$-SR was introduced (Fig. $8 A$ ). As illustrated in Fig. $8 B$, induction of PPAR transcriptional activity by PPAR- $\alpha$ or PGC- $1 \alpha$ overexpression was attenuated when plasmids encoding the RelA NF-кB subunit were cotransfected. Further- more, TNF- $\alpha$ reduced NRF-1 (Fig. $8 C$ ) and Tfam (Fig. $8 D$ ) promoter activity levels by $50 \%$, which was fully restored by blockade of NF-кB signaling through introduction of the IкB $\alpha-S R$ construct. Moreover, transfection of a c.a. IKK- $\beta$ construct also resulted in a $50 \%$ reduction in reporter activities, which in turn was reversed when the IкB $\alpha$-SR was cointroduced in the cell (Fig. 8A, $C, D$ ). Introduction

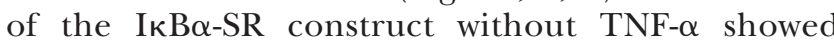
increased PPAR transcriptional activity or NRF-1/ Tfam promoter activity levels compared to control cells. Also, introduction of c.a. IKK- $\beta$ together with the IкB $\alpha$-SR construct increased reporter activity compared to control conditions (Fig. 8A, C, D).

\section{NF- $\kappa \mathrm{B}$ activation is required for impaired mitochondrial respiratory capacity by TNF- $\alpha$}

Basal- and TNF- $\alpha$-induced RelA DNA-binding was assessed by gel shift and found to be abrogated in L6 myotubes stably expressing the I $\mathrm{B} \mathrm{B} \alpha$-SR construct. L6 control myotubes showed increased RelA DNA binding after TNF- $\alpha$ stimulation. In contrast, I $\mathrm{B} \alpha$-SR myotubes revealed markedly lower RelA DNA binding capacity compared to the control cells after TNF- $\alpha$ stimulation. Supershift analysis demonstrates the presence of RelA in the main complex after TNF- $\alpha$ stimulation. (Supplemental Fig. S5). Impaired respiratory capacity of L6 muscle cells on chronic TNF- $\alpha$ stimulation was fully restored by stable blockade of the NF-кB signaling pathway (Fig. 9).

\section{DISCUSSION}

This study shows that expression levels of markers and regulators of muscle oxphen are significantly lower in a subset of patients with COPD with increased muscle
A

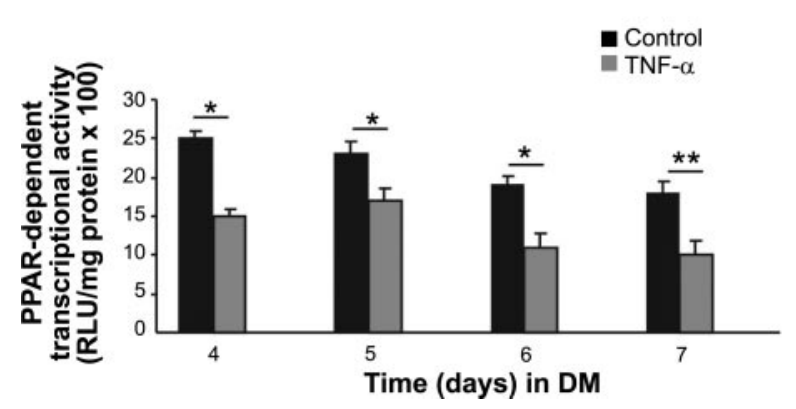

B

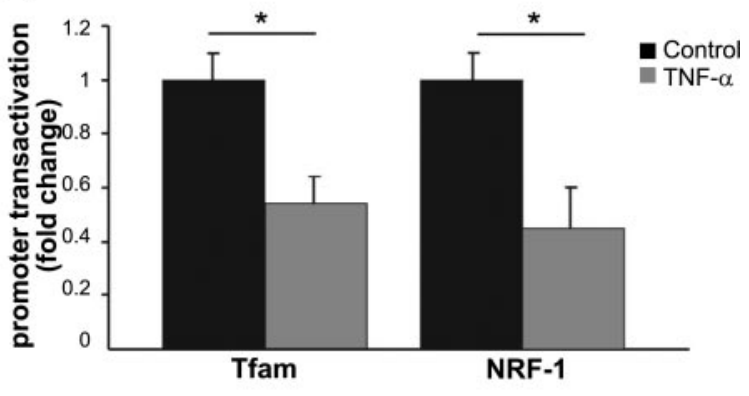

Figure 7. TNF- $\alpha$ reduces activity levels of major regulators of muscle oxphen. A) C2C12 myotubes stably transfected with a PPAR-sensitive promoter reporter construct (containing the cis-acting PPAR responsive element of the CPT-1 promoter) were differentiated for $3 \mathrm{~d}$ in DM. Myotubes were stimulated with vehicle (BSA; control) or TNF- $\alpha$ (10 ng/ml) and harvested every 24 h. B) C2C12 myoblasts were transiently transfected with a Tfam or a NRF-1 promoter reporter construct and stimulated with $\mathrm{TNF}-\alpha(10 \mathrm{ng} / \mathrm{ml})$ or vehicle (BSA: control) for $24 \mathrm{~h}$. Cells were lysed; luciferase activity was determined and normalized to $\beta$-galactosidase (transient transfection) or total protein (stable reporter cell line). $* P \leq 0.05 ; * * P \leq 0.01$. All data are expressed as means $\pm \mathrm{SD}$ from triplicate samples $(n=3$ experiments). 
A

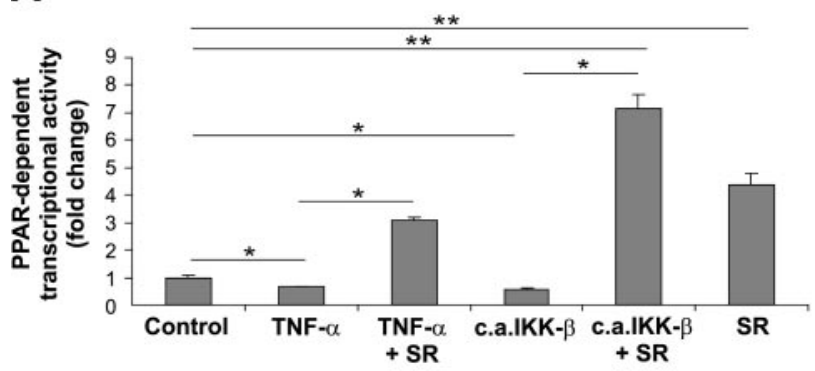

C

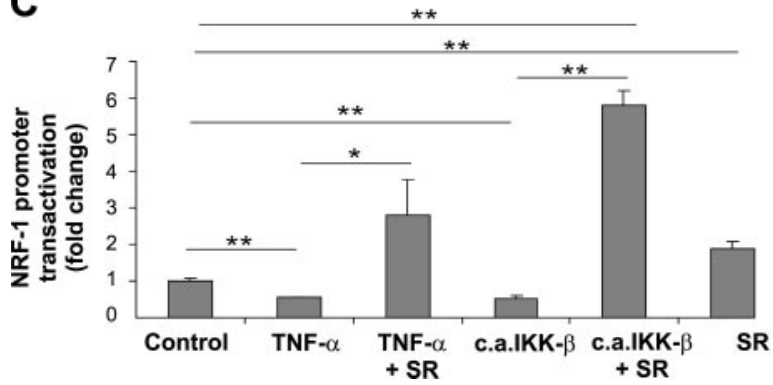

B

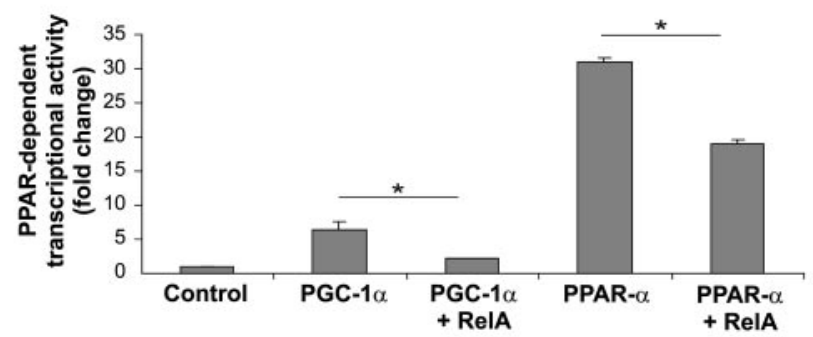

D

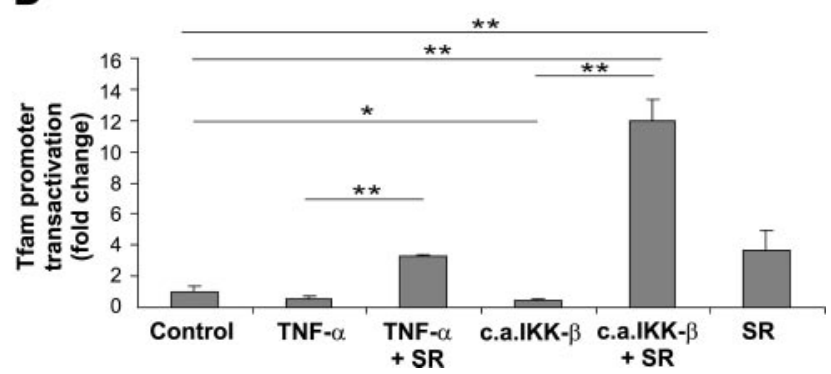

Figure 8. Involvement of NF-кB signaling in TNF- $\alpha$-induced deregulation of oxphen. A) C2C12 myoblasts were cotransfected with a PPAR-sensitive promoter reporter construct (containing the cis-acting PPAR responsive element of the CPT-1 promoter) in combination with empty vector (e.v. pCDNA 3.1; control), an $\mathrm{I} \kappa \mathrm{B} \alpha$ super repressor (SR), and/or a constitutive active IкB kinase $\beta$ (c.a. IKK- $\beta$ ) construct and treated with vehicle (BSA; control) or TNF- $\alpha$ (10 ng/ml) for 24 h. B) C2C12 myoblasts were cotransfected with a PPAR reporter (CPT-1) in combination with e.v. (pCDNA3; control) or plasmids encoding PGC-1 $\alpha$ or PPAR- $\alpha$, with/without RelA (V-Rel avian reticuloendotheliosis viral oncogene homologue A). C, D) C2C12 myoblasts were cotransfected with a NRF-1 promoter reporter construct $(C)$ or a Tfam promoter reporter construct $(D)$ in combination with e.v. (pCDNA3.1; control), SR, and/or c.a. IKK- $\beta$ construct and/or stimulated with TNF- $\alpha$ (10 ng/ml) for $24 \mathrm{~h}$. Cells were lysed, and luciferase activity was determined and normalized to $\beta$-galactosidase. Data are presented as means \pm SD $(n=3$ experiments). Results are depicted as fold induction over control. Error bars $=$ SD. $* P \leq 0.01, * * P \leq 0.001$.

TNF- $\alpha$ mRNA expression compared with patients and healthy smoking control participants with normal muscle $T N F-\alpha$ mRNA expression. The in vitro experiments presented in this paper furthermore reveal that TNF- $\alpha$

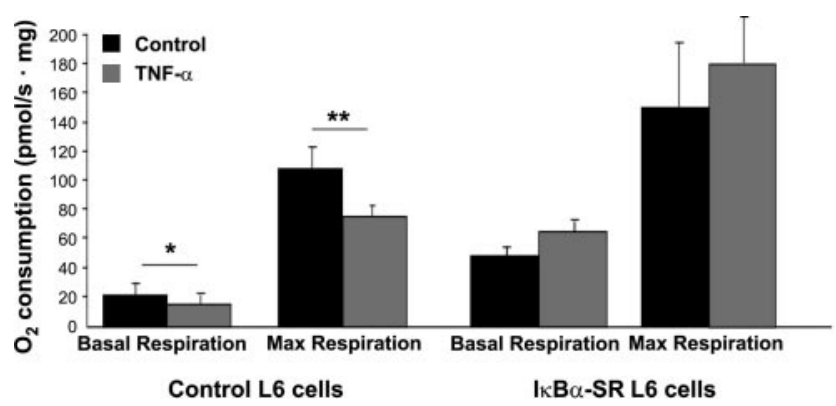

Figure 9. NF- $\mathrm{B}$ activation is required for $\mathrm{TNF}-\alpha$-induced impairment of skeletal muscle respiratory capacity. Control L6 muscle cells or L6 muscle cells with abrogated NF-кB signaling, through stable expression of the IкB $\alpha-\mathrm{SR}$ construct, were differentiated for $3 \mathrm{~d}$ in DM. Myotubes were stimulated with vehicle (BSA; control) or TNF- $\alpha(10 \mathrm{ng} / \mathrm{ml})$ for an additional $120 \mathrm{~h}$. For respiration measurements, the following substances were added to the respiration chambers in the following order and final concentration: digitonin $(1 \mu \mathrm{l} ; 0.5$ $\mu \mathrm{g} / \mathrm{ml})$, malate $(5 \mu \mathrm{l} ; 2 \mathrm{mM})$, palmitoyl-carnitine $(10 \mu \mathrm{l} ; 50$ $\mu \mathrm{M}), \operatorname{ADP}(20 \mu \mathrm{l} ; 5 \mathrm{mM})$, and FCCP $(1 \mu \mathrm{l} ; 0.5 \mu \mathrm{M}$ titration). Cells were harvested, and oxygen consumption was determined. Respiration rates were corrected for total protein content. Data are expressed as means \pm SD from triplicate samples $(n=3$ experiments). $* P \leq 0.05 ; * * P \leq 0.01$. has a direct negative effect on muscle oxphen and its regulation, which is dependent on NF-кB signaling.

As a readout parameter of muscle oxphen, mitochondrial respiratory capacity was diminished on chronic treatment of cultured myotubes with TNF- $\alpha$ in the present study. Interestingly, a recent study demonstrated decreased mitochondrial respiration due to blockade of the electron transport chain, in vastus lateralis as well as respiratory muscles of patients with COPD compared to control participants (25). Although a decreased respiratory capacity has been associated with muscle inactivity, the fact that mitochondrial respiration was affected in respiratory as well peripheral muscle suggests a role for a systemic factor other than muscle disuse (as respiratory muscles in COPD often have an increased workload due to airway obstruction), e.g., inflammation, in impaired respiratory capacity. Unfortunately, systemic or local TNF- $\alpha$ levels were not investigated in that study (25). Decreased mitochondrial respiration following TNF- $\alpha$ stimulation has been reported in experimental models previously (26-28). However, in these particular studies only the acute effects of TNF- $\alpha$ were studied. Other studies revealed inhibition by TNF- $\alpha$ at several sites of the electron transport chain, including complex II, III, and $\mathrm{V}(29,30)$. In contrast, the changes in respiration observed in our in vitro experiments are more likely chronic adaptations resulting from decreased expression of oxphos proteins after sustained incubation with 
TNF- $\alpha$, because the half-life of these proteins is several days (31).

Loss of type I (slow, oxidative) fibers in peripheral skeletal muscle is a very consistent finding in COPD and is related to disease severity as described in a recent meta-analysis $(8,32)$. The exact mechanism underlying this change in fiber type composition to date remains unknown. Intriguingly, chronic TNF- $\alpha$ treatment of cultured myotubes in the present study resulted in a selective reduction of oxidative (type I) $\mathrm{MyHC}$ isoform protein levels, suggesting that deregulated inflammatory events in muscle may underlie a change in fiber type composition. Because it is known that inflammatory stimuli such as TNF- $\alpha$ can activate the proteolytic ubiquitin 26S-proteasome pathway, it is possible that MyHC type I protein is selectively targeted for degradation by this pathway (33). However, increased gene expression levels of MuRF1 and Atrogin, the 2 E3 ligases that target muscle-specific proteins for degradation (34), were not observed after chronic TNF- $\alpha$ stimulation (data not shown). As $M y H C I$ mRNA levels were reduced while expression levels of $M y H C I I b$ were increased after chronic TNF- $\alpha$ stimulation, the reduced protein content of MyHC type I most likely resulted from altered transcriptional control.

The PGC-1 $\alpha /$ PPAR signaling pathway has been shown to be a key regulatory pathway controlling muscle oxphen (35). Therefore, it is feasible that the observed detrimental effects of $\mathrm{TNF}-\alpha$ stimulation on muscle oxphen are mediated through alterations in PPAR and PGC-1 $\alpha$ expression and/or activity levels. Our in vitro observations indeed demonstrate that TNF- $\alpha$ treatment of myotubes results in reduced PPAR transcriptional activity as well as PPAR mRNA expression levels. Also, in the present study, decreased muscle $P P A R / P G C-1 \alpha m R N A$ expression levels in skeletal muscle of patients with COPD were associated with high levels of muscle $T N F-\alpha$ mRNA. In addition, previous work from our group has shown that expression levels of PPARs and their coactivator PGC- $1 \alpha$ are reduced in peripheral skeletal muscle of patients with COPD and correlate negatively with plasma inflammatory markers as TNF- $\alpha$ (14).

The C2C12 as well as the L6 cell line is widely used to study the molecular mechanisms underlying skeletal muscle pathology, e.g., insulin resistance and skeletal muscle atrophy associated with chronic disorders, e.g., COPD and diabetes mellitus. However, caution is warranted with extrapolating in vitro findings to the human situation. Although in many instances in vitro data has yielded insights that were later verified in animals or humans, C2C12 and L6 cells are immortalized cell lines that may not necessarily mimic the in vivo situation. For example, in humans, fiber type/MyHC expression differences/changes are driven by transitions of already established fiber phenotypes (e.g., shift from glycolytic to oxidative on exercise training) while, e.g., in C2C12 cells both MyHC slow and fast isoforms are present. Furthermore, Guttridge et al. (36) found that cytokines altered myofilament protein content in C2C12 myotubes by down-regulating gene transcription, while in the actual complex disease setting (i.e., cancer) they found that the myofilament protein loss was explained instead by increased proteolysis. Also, TNF- $\alpha$ administration to humans did not result in altered systemic and skeletal muscle protein turnover in contrast to what was observed in in vitro studies (37). In light of this knowledge, the in vitro data presented in the present manuscript are to be considered as proof of principal evidence for TNF- $\alpha$ being one possible mechanism leading to impaired muscle oxphen in complex chronic disorders, albeit that involvement of other mechanisms, such as physical inactivity, hypoxia, and oxidative stress, cannot be discarded (38, 39). In particular, the fact that we did not assess physical activity levels of patients and control participants is unfortunate, as inactivity has been shown to be a major determinant of skeletal muscle oxphen (40-42). Therefore, efforts have to be made in future studies to elucidate the exact contribution of these different disease-related parameters to skeletal muscle dysfunction in COPD and other chronic diseases.

In our in vitro system, chronic stimulation of muscle cells with the proinflammatory cytokine IL-1 $\beta$ resulted in an induction of TNF- $\alpha$ mRNA. This is in line with the induction of TNF- $\alpha$ mRNA in C2C12 myotubes after TNF- $\alpha$ stimulation and induction of TNF- $\alpha$ mRNA in the muscle of mice subjected to intramuscular injections with TNF- $\alpha$, which both have been described by our group previously (24). In the present study, stimulation of mature C2C12 myotubes with an inflammatory cytokine (TNF- $\alpha$ or IL-1 $\beta$ ) also resulted in production and secretion of $\mathrm{TNF}-\alpha$ protein by the cells. Collectively, this indicates that increased TNF- $\alpha$ mRNA levels in muscle can be considered as a "signature" revealing (previous) exposure to an inflammatory stimulus. Moreover, these data also demonstrate that myofibers themselves may contribute to the local inflammatory milieu, which is line with the autoamplificatory signaling described for this cytokine (24) and suggests that increased TNF- $\alpha$ mRNA levels in the biopsies from the human subjects may reflect autocrine or circulating cytokine actions. It is important to note that data on TNF- $\alpha$ mRNA or protein expression in skeletal muscle of patients with COPD appear to be conflicting. The limited studies that have been performed so far showed no detectable $T N F-\alpha$ mRNA levels (43), increased TNF- $\alpha$ protein levels (44), or even lower levels of $\mathrm{TNF}-\alpha$ protein in skeletal muscle of patients with COPD compared with control participants (45). In our study $\sim 25 \%$ of the patients exhibited elevated $T N F-\alpha$ mRNA levels confirming the heterogeneity of the disease and the need for appropriate phenotyping with respect to both pulmonary and systemic impairment (46). In none of the patients could we detect TNF- $\alpha$ protein in the muscle biopsies. This may suggest that, on production, TNF- $\alpha$ is secreted from the muscle cells.

As mentioned earlier, smoking is the most important risk factor for developing COPD in the western world. In this context, a very recent study showed that chronic smoke inhalation of mice (as a model for COPD) resulted in increased circulatory levels of 
TNF- $\alpha$, which was associated with diminished exercise endurance, reduced muscle oxphen, and decreased muscular levels of PGC- $1 \alpha$. These researchers also showed that treatment of C2C12 myotubes with TNF- $\alpha$ resulted in decreased levels of $P G C-1 \alpha$ similar to our observations (47).

In the present study, the patients with high $T N F-\alpha$ levels (which consisted of $\sim 25 \%$ of the total COPD group investigated) were also characterized by lower BMI and a trend toward lower FFMI (as a marker for muscle mass). This suggests that inflammatory signaling might be associated with both weight loss and loss of muscle mass as well as impairment of muscle oxphen. In line with this notion, it has been shown that cachectic patients with COPD often display a more pronounced loss of muscle oxphen compared with noncachectic patients (48). Moreover, we previously showed that expression levels of major regulators of muscle oxphen such as PPAR- $\alpha$ and Tfam are significantly lower in muscle of cachectic patients compared with noncachectic patients (14). These collective findings suggest that an elevated inflammatory status, as observed in COPD, might be a trigger, not only for the loss of muscle mass but also for loss of muscle oxphen.

More mechanistic insight into the effect of TNF- $\alpha$ on skeletal muscle oxphen was provided by the finding that genetic blockade of the NF-кB signaling pathway inhibited TNF- $\alpha$-induced reductions in mitochondrial respiratory capacity and PPAR transcriptional activity in cultured muscle cells. Moreover, activating NF-кB signaling by overexpression of c.a. IKK- $\beta$ was sufficient to reproduce the effect of TNF- $\alpha$ on PPAR transcriptional activity. Similarly, RelA overexpression attenuated PGC$1 \alpha$-induced PPAR transcriptional activity. Although PPARs have been shown to be able to interfere with the NF-кB pathway (49-52), few studies have reported a negative effect of NF- $\kappa$ B signaling on the PGC-1 $\alpha$ PPAR pathway, and so far no data are available in skeletal muscle. Our findings now demonstrate that the NF- $\kappa$ B pathway mediates TNF- $\alpha$-induced inhibition of skeletal muscle mitochondrial respiratory capacity and PPAR transcriptional activity in vitro. In addition, promoter activity levels of NRF-1 and Tfam, 2 important regulators of mitochondrial biogenesis, were also reduced on TNF- $\alpha$ stimulation in a NF- $\mathrm{B}$-dependent manner. These observations suggest that, in addition to decreased PPAR activity, specific components implicated in regulation of mitochondrial biogenesis could also be impaired by TNF- $\alpha$-induced NF- $\mathrm{B}$ activation. Surprisingly, blockade of c.a. IKK- $\beta$-induced NF-кB activity by the I $\mathrm{B} \alpha-\mathrm{SR}$ resulted in an increase in activity levels of the PPARs, Tfam, and NRF-1 compared with control conditions. We speculate that this may point toward a more complex regulation of PPARs, NRF-1, and Tfam activity by IKK- $\beta / \mathrm{NF}-\kappa \mathrm{B}$ signaling, in which nuclear translocation of NF- $\mathrm{KB}$ decreases PPAR-, NRF$1-$, and Tfam activity, whereas IKK- $\beta$ activation, in the absence of nuclear translocation of NF- $\mathrm{B}$, actually stimulates PPAR-, NRF-1-, and Tfam activity. Therefore, the selective manipulation of the subunits of the IKK complex may stimulate oxphen in absence of RelA translocation as has been shown for IKK- $\alpha$ by Bakkar et al. (53).

Detrimental effects of TNF- $\alpha$ signaling are not restricted to impaired muscle oxphen. Loss of skeletal muscle mass and impaired myogenic differentiation, both mediated through the NF-кB pathway $(11,18,54)$, are well documented in skeletal muscle. Importantly, we show that the impairment of skeletal muscle oxphen mediated by TNF- $\alpha$ in the present study is not a consequence of impaired myogenic differentiation or decreased protein content.

To the best of our knowledge, this is the first report demonstrating a direct and clear negative interaction between inflammatory mediators as TNF- $\alpha$, subsequent NF-кB signaling, and skeletal muscle oxphen. A recent clinical trial provided indirect support for these findings, as anti-inflammatory modulation by polyunsaturated fatty acids enhanced exercise capacity in patients with COPD participating in a pulmonary rehabilitation program (55).

Collectively, in light of these results, targeted inhibition of the NF-kB pathway could prove to be beneficial in multiple chronic inflammatory conditions characterized by disturbed muscle oxphen. Interestingly, our group recently demonstrated that PPAR- $\gamma$ activation by rosiglitazone, which is currently in use for the treatment of type 2 diabetes mellitus (T2DM), potently inhibited cytokineinduced NF- $\mathrm{B}$ activation in cultured muscle cells. Moreover, rosiglitazone treatment of T2DM patients has been shown to increase skeletal muscle oxphen and restore $P G C-1 \alpha / P P A R$ expression levels (56).

In summary, the body of data presented in the present work demonstrates that chronically elevated TNF- $\alpha$ levels potently reduce both structural and metabolic aspects that determine oxphen of cultured skeletal muscle cells. This inflammation-associated impairment of muscle oxphen resulted from disturbed regulatory processes, as TNF- $\alpha$ down-regulated expression and activity levels of main regulators of muscle oxphen capacity and mitochondrial biogenesis. In addition, our in vitro data also show that deregulation of skeletal muscle oxphen by chronic TNF- $\alpha$ stimulation occurs in a NF-кB-dependent manner providing a mechanistic explanation. These results may provide new leads for alleviation of skeletal muscle dysfunction in COPD and possibly also other chronic inflammatory disorders.

The authors thank Dr. S. Wagers for critical and careful reviewing of the content of the paper and assistance with English. The authors also thank Dr. Marc van Bilsen (Maastricht University, Maastricht, The Netherlands) for delivering constructs encoding PPAR isoforms and PGC- $1 \alpha$. The authors acknowledge E. Phielix for excellent technical support in cellular respiration measurements and M. Kelders for practical help in carrying out QPCR procedures. The authors have no conflicting financial interests. Funding sources had no involvement in collection, analysis, and interpretation of data; in the writing of the report; and in the decision to submit the paper for publication. The research of H.R.G. is supported by a grant from the Netherlands Asthma Foundation (NAF 3.4.05.038). The research of P. Schrauwen has been made 
possible by fellowships of the Royal Netherlands Academy of Arts and Sciences. R.C.J.L. was sponsored by a VENI grant (VENI 916.56.112). A.H.V.R. is supported by a grant from Numico Research and a travel fellowship from the Netherlands Asthma Foundation (NAF 3.2.08.061). The ENIGMA study was sponsored by ENIGMA grant QLK6-CT-2002-02285.

\section{REFERENGES}

1. Tisdale, M. J. (2009) Mechanisms of cancer cachexia. Physiol Rev. 89, 381-410

2. Pajak, B., Orzechowska, S., Pijet, B., Pijet, M., Pogorzelska, A., Gajkowska, B., and Orzechowski, A. (2008) Crossroads of cytokine signaling: the chase to stop muscle cachexia. J. Physiol. Pharmacol. 59(Suppl. 9), 251-264

3. Schols, A. M., Soeters, P. B., Dingemans, A. M., Mostert, R., Frantzen, P. J., and Wouters, E. F. (1993) Prevalence and characteristics of nutritional depletion in patients with stable COPD eligible for pulmonary rehabilitation. Am. Rev. Respir. Dis. 147, 1151-1156

4. Vermeeren, M. A., Creutzberg, E. C., Schols, A. M., Postma, D. S., Pieters, W. R., Roldaan, A. C., and Wouters, E. F. (2006) Prevalence of nutritional depletion in a large out-patient population of patients with COPD. Respir. Med. 100, 1349-1355

5. Schols, A. M., Broekhuizen, R., Weling-Scheepers, C. A., and Wouters, E. F. (2005) Body composition and mortality in chronic obstructive pulmonary disease. Am. J. Clin. Nutr. 82, 53-59

6. Sin, D. D., and Man, S. F. (2007) Systemic inflammation and mortality in chronic obstructive pulmonary disease. Can. J. Physiol. Pharmacol. 85, 141-147

7. Gan, W. Q., Man, S. F., Senthilselvan, A., and Sin, D. D. (2004) Association between chronic obstructive pulmonary disease and systemic inflammation: a systematic review and a meta-analysis. Thorax 59, 574-580

8. Gosker, H., Zeegers, M., Wouters, E., and Schols, A. M. (2007) Muscle fibre type shifting in the vastus lateralis of patients with COPD is associated with disease severity: a systematic review and meta-analysis. Thorax 62, 944-949

9. Gosker, H. R., Engelen, M. P., van Mameren, H., van Dijk, P. J., van der Vusse, G. J., Wouters, E. F., and Schols, A. M. (2002) Muscle fiber type IIX atrophy is involved in the loss of fat-free mass in chronic obstructive pulmonary disease. Am. J. Clin. Nutr. 76, 113-119

10. Cerami, A., Ikeda, Y., Le Trang, N., Hotez, P. J., and Beutler, B. (1985) Weight loss associated with an endotoxin-induced mediator from peritoneal macrophages: the role of cachectin (tumor necrosis factor). Immunol. Lett. 11, 173-177

11. Cai, D., Frantz, J. D., Tawa, N. E., Jr., Melendez, P. A., Oh, B. C., Lidov, H. G., Hasselgren, P. O., Frontera, W. R., Lee, J., Glass, D. J., and Shoelson, S. E. (2004) IKKbeta/NF-kappaB activation causes severe muscle wasting in mice. Cell 119, 285-298

12. Tracey, K. J., Wei, H., Manogue, K. R., Fong, Y., Hesse, D. G., Nguyen, H. T., Kuo, G. C., Beutler, B., Cotran, R. S., Cerami, A., and Lowry, S. F. (1988) Cachectin/tumor necrosis factor induces cachexia, anemia, and inflammation. J. Exp. Med. 167, $1211-1227$

13. Lee, M. D., Zentella, A., Vine, W., Pekala, P. H., and Cerami, A. (1987) Effect of endotoxin-induced monokines on glucose metabolism in the muscle cell line L6. Proc. Natl. Acad. Sci. U. S. A. 84, 2590-2594

14. Remels, A. H., Schrauwen, P., Broekhuizen, R., Willems, J., Kersten, S., Gosker, H. R., and Schols, A. M. (2007) Expression and content of PPARs is reduced in skeletal muscle of COPD patients. Eur. Respir. J. 30, 245-252

15. Fabbri, L., Pauwels, R. A., and Hurd, S. S. (2004) Global strategy for the diagnosis, management, and prevention of chronic obstructive pulmonary disease: GOLD executive summary updated 2003. COPD 1, 105-141; discussion 103-104

16. Gosker, H. R., Langen, R. C., Bracke, K. R., Joos, G. F., Brusselle, G. G., Steele, C., Ward, K. A., Wouters, E. F., and Schols, A. M. (2009) Extrapulmonary manifestations of chronic obstructive pulmonary disease in a mouse model of chronic cigarette smoke exposure. Am. J. Respir. Cell Mol. Biol. 40, 710-716
17. Van Wetering, C. R., Hoogendoorn, M., Broekhuizen, R., Geraerts-Keeris, G. J., De Munck, D. R., Rutten-van Molken, M. P., and Schols, A. M. (2010) Efficacy and costs of nutritional rehabilitation in muscle-wasted patients with chronic obstructive pulmonary disease in a community-based setting: a prespecified subgroup analysis of the INTERCOM trial. J. Am. Med. Dir. Assoc. 11, 179-187

18. Langen, R. C., Schols, A. M., Kelders, M. C., Wouters, E. F., and Janssen-Heininger, Y. M. (2001) Inflammatory cytokines inhibit myogenic differentiation through activation of nuclear factorkappaB. FASEB J. 15, 1169-1180

19. Wu, Z., Puigserver, P., Andersson, U., Zhang, C., Adelmant, G., Mootha, V., Troy, A., Cinti, S., Lowell, B., Scarpulla, R. C., and Spiegelman, B. M. (1999) Mechanisms controlling mitochondrial biogenesis and respiration through the thermogenic coactivator PGC-1. Cell 98, 115-124

20. Gugneja, S., Virbasius, C. M., and Scarpulla, R. C. (1996) Nuclear respiratory factors 1 and 2 utilize similar glutaminecontaining clusters of hydrophobic residues to activate transcription. Mol. Cell. Biol. 16, 5708-5716

21. Gosker, H. R., Schrauwen, P., Broekhuizen, R., Hesselink, M. K., Moonen-Kornips, E., Ward, K. A., Franssen, F. F., Wouters, E. F., and Schols, A. M. (2005) Exercise training restores uncoupling protein-3 content in limb muscles of patients with chronic obstructive pulmonary disease. Am. J. Physiol. Endocrinol. Metab. 290, E976-E981

22. Van der Velden, J., Langen, R., Kelders, M., Willems, J., Wouters, E., Janssen-Heininger, Y., and Schols, A. (2006) Myogenic differentiation during regrowth of atrophied skeletal muscle is associated with inactivation of GSK-3 3 . Am. J. Physiol. Cell. Physiol. 292, C1636-C1644

23. Altman, D. G., Gore, S. M., Gardner, M. J., and Pocock, S. J. (1983) Statistical guidelines for contributors to medical journals. Br. Med. J. (Clin. Res. Ed.) 286, 1489-1493

24. Langen, R. C., Schols, A. M., Kelders, M. C., van der Velden, J. L., Wouters, E. F., and Janssen-Heininger, Y. M. (2006) Muscle wasting and impaired muscle regeneration in a murine model of chronic pulmonary inflammation. Am. J. Respir. Cell Mol. Biol. 35, 689-696

25. Puente-Maestu, L., Perez-Parra, J., Godoy, R., Moreno, N. Tejedor, A., Gonzalez-Aragoneses, F., Bravo, J. L., Alvarez, F. V., Camano, S., and Agusti, A. (2009) Abnormal mitochondrial function in locomotor and respiratory muscles of COPD patients. Eur. Respir. J. 33, 1045-1052

26. Lancaster, J. R., Jr., Laster, S. M., and Gooding, L. R. (1989) Inhibition of target cell mitochondrial electron transfer by tumor necrosis factor. FEBS Lett. 248, 169-174

27. Schulze-Osthoff, K., Bakker, A. C., Vanhaesebroeck, B., Beyaert, R., Jacob, W. A., and Fiers, W. (1992) Cytotoxic activity of tumor necrosis factor is mediated by early damage of mitochondrial functions: evidence for the involvement of mitochondrial radical generation. J. Biol. Chem. 267, 5317-5323

28. Valerio, A., Cardile, A., Cozzi, V., Bracale, R., Tedesco, L., Pisconti, A., Palomba, L., Cantoni, O., Clementi, E., Moncada, S., Carruba, M. O., and Nisoli, E. (2006) TNF-alpha downregulates eNOS expression and mitochondrial biogenesis in fat and muscle of obese rodents. J. Clin. Invest. 116, 2791-2798

29. Jia, L., Kelsey, S. M., Grahn, M. F., Jiang, X. R., and Newland, A. C. (1996) Increased activity and sensitivity of mitochondrial respiratory enzymes to tumor necrosis factor alpha-mediated inhibition is associated with increased cytotoxicity in drugresistant leukemic cell lines. Blood 87, 2401-2410

30. Marin-Garcia, J., Goldenthal, M. J., and Moe, G. W. (2001) Abnormal cardiac and skeletal muscle mitochondrial function in pacing-induced cardiac failure. Cardiovasc. Res. 52, 103-110

31. Lyons, C. N., Leary, S. C., and Moyes, C. D. (2004) Bioenergetic remodeling during cellular differentiation: changes in cytochrome c oxidase regulation do not affect the metabolic phenotype. Biochem. Cell Biol. 82, 391-399

32. Gosker, H. R., van Mameren, H., van Dijk, P. J., Engelen, M. P., van der Vusse, G. J., Wouters, E. F., and Schols, A. M. (2002) Skeletal muscle fibre-type shifting and metabolic profile in patients with chronic obstructive pulmonary disease. Eur. Respir. J. 19, 617-625

33. Jackman, R. W., and Kandarian, S. C. (2004) The molecular basis of skeletal muscle atrophy. Am. J. Physiol. Cell Physiol. 287, C834-C843 
34. Attaix, D., Ventadour, S., Codran, A., Bechet, D., Taillandier, D., and Combaret, L. (2005) The ubiquitin-proteasome system and skeletal muscle wasting. Essays Biochem. 41, 173-186

35. Luquet, S., Lopez-Soriano, J., Holst, D., Fredenrich, A., Melki, J., Rassoulzadegan, M., and Grimaldi, P. A. (2003) Peroxisome proliferator-activated receptor delta controls muscle development and oxidative capability. FASEB J. 17, 2299-2301

36. Acharyya, S., Ladner, K. J., Nelsen, L. L., Damrauer, J., Reiser, P. J., Swoap, S., and Guttridge, D. C. (2004) Cancer cachexia is regulated by selective targeting of skeletal muscle gene products. J. Clin. Invest. 114, 370-378

37. Petersen, A. M., Plomgaard, P., Fischer, C. P., Ibfelt, T., Pedersen, B. K., and van Hall, G. (2009) Acute moderate elevation of TNF-alpha does not affect systemic and skeletal muscle protein turnover in healthy humans. J. Clin. Endocrinol. Metab. 94, 294-299

38. Wust, R. C., and Degens, H. (2007) Factors contributing to muscle wasting and dysfunction in COPD patients. Int. J. Chron. Obstruct. Pulmon. Dis. 2, 289-300

39. Couillard, A., and Prefaut, C. (2005) From muscle disuse to myopathy in COPD: potential contribution of oxidative stress. Eur. Respir. J. 26, 703-719

40. Safdar, A., Hamadeh, M. J., Kaczor, J. J., Raha, S., Debeer, J., and Tarnopolsky, M. A. (2010) Aberrant mitochondrial homeostasis in the skeletal muscle of sedentary older adults. PLoS ONE 5, e10778

41. Chabi, B., Adhihetty, P. J., O'Leary, M. F., Menzies, K. J., and Hood, D. A. (2009) Relationship between Sirt1 expression and mitochondrial proteins during conditions of chronic muscle use and disuse. J. Appl. Physiol. 107, 1730-1735

42. Lanza, I. R., and Sreekumaran Nair, K. (2010) Regulation of skeletal muscle mitochondrial function: genes to proteins. Acta Physiol. (Oxf.) 199, 529-547

43. Crul, T., Spruit, M. A., Gayan-Ramirez, G., Quarck, R., Gosselink, R., Troosters, T., Pitta, F., and Decramer, M. (2007) Markers of inflammation and disuse in vastus lateralis of chronic obstructive pulmonary disease patients. Eur. J. Clin. Invest. 37, 897-904

44. Montes de Oca, M., Torres, S. H., De Sanctis, J., Mata, A., Hernandez, N., and Talamo, C. (2005) Skeletal muscle inflammation and nitric oxide in patients with COPD. Eur. Respir. J. 26, 390-397

45. Barreiro, E., S.A., Polkey, M., Galdiz, J., Gosker, H., Swallow, E., Coronell, C., and Gea, J. (2007) Cytokine profile in quadriceps muscle of patients with severe chronic obstructive pulmonary disease. Thorax 63, 100-107

46. Barnes, P. J., and Celli, B. R. (2009) Systemic manifestations and comorbidities of COPD. Eur. Respir. J. 33, 1165-1185

47. Tang, K., Wagner, P. D., and Breen, E. C. (2010) TNF-alpha-mediated reduction in PGG-1alpha may impair skeletal muscle function after cigarette smoke exposure. J. Cell. Physiol. 222, 320-327
48. Rabinovich, R. A., Bastos, R., Ardite, E., Llinas, L., Orozco-Levi, M., Gea, J., Vilaro, J., Barbera, J. A., Rodriguez-Roisin, R., Fernandez-Checa, J. C., and Roca, J. (2007) Mitochondrial dysfunction in COPD patients with low body mass index. Eur. Respir. J. 29, 643-650

49. Pascual, G., Fong, A. L., Ogawa, S., Gamliel, A., Li, A. C., Perissi, V., Rose, D. W., Willson, T. M., Rosenfeld, M. G., and Glass, C. K. (2005) A SUMOylation-dependent pathway mediates transrepression of inflammatory response genes by PPAR-gamma. Nature 437, 759-763

50. Remels, A. H., Langen, R. C., Gosker, H. R., Russell, A. P., Spaapen, F., Voncken, J. W., Schrauwen, P., and Schols, A. M. (2009) PPARgamma inhibits NF-kappaB-dependent transcriptional activation in skeletal muscle. Am. J. Physiol. Endocrinol. Metab. 297, E174-E183

51. Delerive, P., De Bosscher, K., Besnard, S., Vanden Berghe, W., Peters, J. M., Gonzalez, F. J., Fruchart, J. C., Tedgui, A., Haegeman, G., and Staels, B. (1999) Peroxisome proliferator-activated receptor alpha negatively regulates the vascular inflammatory gene response by negative cross-talk with transcription factors NF-kappaB and AP-1. J. Biol. Chem. 274, 32048-32054

52. Zhao, C. Y., Wang, J. B., Deng, Z. J., Liu, J. W., Li, J. M., Li, L., and Jiang, L. L. (2005) Relationship between NF-kappa B binding activity and expression of PPAR gamma-mRNA in the livers of rats with fatty liver disease. [In Chinese] Zhonghua Gan Zang Bing Za Zhi 13, 96-100

53. Bakkar, N., Wang, J., Ladner, K. J., Wang, H., Dahlman, J. M., Carathers, M., Acharyya, S., Rudnicki, M. A., Hollenbach, A. D., and Guttridge, D. C. (2008) IKK/NF-kappaB regulates skeletal myogenesis via a signaling switch to inhibit differentiation and promote mitochondrial biogenesis. J. Cell Biol. 180, 787-802

54. Guttridge, D. C., Mayo, M. W., Madrid, L. V., Wang, C. Y., and Baldwin, A. S., Jr. (2000) NF-kappaB-induced loss of MyoD messenger RNA: possible role in muscle decay and cachexia Science 289, 2363-2366

55. Broekhuizen, R., Wouters, E. F., Creutzberg, E. C., WelingScheepers, C. A., and Schols, A. M. (2005) Polyunsaturated fatty acids improve exercise capacity in chronic obstructive pulmonary disease. Thorax 60, 376-382

56. Mensink, M., Hesselink, M. K., Russell, A. P., Schaart, G., Sels, J. P., and Schrauwen, P. (2007) Improved skeletal muscle oxidative enzyme activity and restoration of PGC-1 alpha and PPAR beta/delta gene expression upon rosiglitazone treatmen in obese patients with type 2 diabetes mellitus. Int. J. Obes. (Lond.) 31, 1302-1310

Received for publication January 4, 2010 Accepted for publication July 15, 2010. 